\title{
5
}

\section{MIEDO, REVERENCIA, TERROR CINCO ENSAYOS DE ICONOGRAFÍA POLÍTICA}

\author{
Carlo Ginzburg \\ Prohistoria Ediciones - Contrahistorias, Rosario/México, 2018. \\ 189 pp. ISBN 978-987-3864-96-4
}

Fabiana Alonso

En los años noventa, el historiador británico Perry Anderson sostuvo que su colega italiano Carlo Ginzburg había hecho mérito suficiente como para ser considerado el más notable historiador europeo que llegó a la mayoría de edad a fines de la década de 1960. En efecto, Ginzburg es mundialmente conocido no sólo por ser un notable representante de la microhistoria, sino también por tratarse de un historiador que le imprime originalidad al tratamiento de sus temas de investigación y que combina, como pocos, erudición y competencias teóricas.

En sus obras está presente la preocupación por la conexión entre pruebas, verdad e historia; por la relación entre las fuentes y el pasado que se pretende reconstruir y por la dimensión narrativa de la historiografía. Su original estilo de escritura hace participar al lector en sus propios recorridos investigativos y en la construcción de los objetos de conocimiento, develando que eso que llamamos «lo real» no es algo dado, sino que es resultado de un análisis.

El libro que nos ocupa consta de cinco ensayos de iconografía política y sesenta páginas de ilustraciones a color. Publicados entre 2001 y 2011, refieren a distintos temas que giran en torno al terror y sus gestos. No obstante, el instrumento analítico común a todo ellos es la noción de Pathosformeln (que puede traducirse como «fórmulas de emoción» o «fórmulas expresivas»), propuesta por 
Aby Warburg (1866-1929), historiador del arte de origen alemán. Basándonos en José E. Burucúa (2006), conocedor de la obra de Warburg, se puede definir la noción como un conglomerado de formas expresivas y significantes históricamente determinado que configura un horizonte de civilización, atravesando etapas de latencia, recuperación, apropiación y metamorfosis.

El primer ensayo está dedicado al análisis de una copa de plata dorada fabricada en Amberes entre 1524 y 1525. Ginzburg realiza un análisis morfológico deteniéndose en las escenas que decoran el pie, el cuerpo y la tapa. Su interpretación se diferencia de las realizadas previamente, la mayoría de las cuales consideraron las escenas como representaciones de poblaciones exóticas. Su perspectiva toma como referencia la memoria y la distancia para argumentar que la memoria cultural fue utilizada para llenar las lagunas de la distancia geográfica. Los escritores, anticuarios, pintores y escultores europeos se apoyaron en la herencia griega y romana para dar cuenta de las poblaciones de América. Así, el Nuevo Mundo fue percibido, comprendido y convertido en algo familiar a través del lenguaje visual de la antigüedad clásica recuperado a través del Renacimiento italiano.

El segundo ensayo consiste en una relectura de Hobbes. Lo hace pensando en el mundo que nos toca vivir, en el cual se utiliza la religión como arma y los Estados utilizan la amenaza del terror. Analiza el frontispicio del Leviathan (1651), en el que se representa al Estado sosteniendo la espada en una mano, y el báculo en la otra. Según Ginzburg, Hobbes resalta que el poder del Estado está basado no sólo en la fuerza, sino también en el terror. Su interpretación va a contramano de aquélla que sostiene que Hobbes inauguró la filosofía política moderna, al proponer por primera vez una interpretación secularizada de los orígenes del Estado. Para Ginzburg, la tradición inaugurada por Hobbes articula Estado y teología política. El Estado, ese «dios mortal», dispone de la fuerza, pero ésta sola es insuficiente. Por lo cual el Estado hace nacer el terror, sentimiento que combina el temor y la intimidación. Para presentarse como autoridad legítima el Estado necesita del instrumento de la religión, lo que obligaría a abordar desde una perspectiva diferente a la secularización, que más que oponerse a la religión invade su terreno; proceso que, por otra parte, no ha concluido.

El ensayo siguiente está dedicado a «Marat en su último suspiro», una pintura de Jacques-Louis David de 1793. A propósito del culto republicano de Marat en la Francia revolucionaria, Ginzburg explora las interrelaciones entre arte, política 
y religión. En este cuadro, el primero fechado en base a un calendario ausente de connotaciones cristianas, se entrelazan tradiciones distintas y distantes: la griega, la romana y la cristiana. La república, nacida de la derrota y de la destrucción de la monarquía de derecho divino, buscaba una legitimidad suplementaria invadiendo la esfera de lo sagrado, en la que la religión civil tenía en ese momento el monopolio histórico. Marat, mártir republicano, podía ser representado como un santo. Al igual que el análisis del frontispicio del Leviathan de Hobbes, este ensayo responde al interés por indagar los diversos rostros de la secularización; en este caso, las formas en que el poder secular se apropia del aura de la religión.

El cuarto ensayo incursiona en el lenguaje de la publicidad política. A partir de un póster británico en el que aparece Lord Kitchener — militar que había llegado a ser gobernador de Egipto- Ilamando a unirse al ejército durante la primera guerra mundial, Ginzburg identifica posteriores reelaboraciones en pósters estadounidenses, italianos, alemanes y soviéticos, producidos entre 1914 y 1944. Se pregunta cómo actuaron esos carteles, esto es, qué dispositivos visuales y verbales los hicieron eficaces. En su interpretación, la adaptación de dispositivos visuales clásicos para una audiencia del siglo XX acostumbrada al cine, explicaría la eficacia simbólica de esas producciones.

El último ensayo está dedicado al «Guernica» de Picasso, en tanto que pintura antifascista que representa una comunidad de seres humanos y animales unidos por la tragedia y la muerte. Describe las circunstancias políticas de su producción y luego se centra en el orden formal de resonancias clásicas. Lo pone en relación con otras obras de Picasso y con pinturas de otras épocas que se caracterizan por tener dimensiones similares. No se detiene en la recepción de la obra de arte, sino que le interesa su gestación, es decir, la obra en proceso.

La variedad temática, las estrategias de análisis y la calidad de la escritura convierten al libro de Ginzburg en una obra atractiva para un público académico amplio.

\section{REFERENCIAS BIBLIOGRÁFICAS}

Anderson, P. (1994). Pesquisa nocturna: Carlo Ginzburg. Secuencia. Revista de historia y ciencias sociales, № 29, México, 191-216.

Burucúa, J.E. (2006). Historia y ambivalencia. Ensayos sobre arte. Buenos Aires: Biblos. 